\title{
JOB DISSATISFACTION AND TURNOVER: BANGLADESH PERSPECTIVE
}

\author{
Md. Shamim Talukder, Lecturer \\ Md. Farid Hossain Talukder, Lecturer \\ Md. Jahangir Alam, Assistant Prof. \\ Department of Management, \\ Bangladesh University of Business \& Technology (BUBT)
}

Doi: 10.19044/elp.v1no2a15 URL:http://dx.doi.org/10.19044/elp.v1no2a15

\begin{abstract}
The process of job turnover can be described as job dissatisfaction is the first step, followed by intention to leave, which finally, can result in actual turnover (Mobley et al. 1978; Bannister \& Griffith 1986). This article aimed at identifying the empirical evidences of turnover in three different situations: i) being dissatisfied with the previous job, ii) availability of job in the market and iii) (search for) better alternative job as well as identifying the factors affect job dissatisfaction. In order to collect data for this study a comprehensive questionnaire was distributed to 150 employees of different private and public organization in Bangladesh who already leaved their previous job, of them 140 usable responses were received (drop-out rate: 6.67 percent). The results showed that the rates of turnover in three different situations are $33 \%, 25 \%$ and $52.5 \%$ respectively. The most important factors which affect job dissatisfaction are working environment \& administration, supervisors \& working hours and security of income (future) etc. A final conclusion of this study is that, the organizations experience excessive rate of job turnover should consider the said factors to retain their employees.
\end{abstract}

Keywords: Job turnover, Turnover situations, Commitment, Job dissatisfaction

\section{Introduction}

Employee turnover technically projects the rate of employees leaving a company and new employees filling up their positions. Employee turnover is not a good thing for any company as it directly hits the cost aspect. And yes, employee turnover is expensive (Jose 2013). Simply job turnover refers to the situation when employee quit his or her job. It is basically resulting from dissatisfaction about job or the lack of commitment. The process of job 
turnover can be described as job dissatisfaction is the first step, followed by intention to leave, which finally, in some cases, can result in actual turnover (Mobley et al. 1978; Bannister \& Griffith 1986). This process is, of course, of varying duration in time and does not necessarily have to follow a straight line. A person may move back and forth between job dissatisfaction and intention to leave or remain in this 'borderland' for longer periods (Tham 2006). The main focus of the study was, to show the rate of turnover in three different situations as: I) being dissatisfied with the previous job; II) availability of job in the market and III) search for better alternative job as well as to explore the factors responsible for job dissatisfaction.

\section{Prior empirical works}

Dissatisfaction can only arise from the experience of bad surprises with the current job, good surprises with current opportunities, or unexpected binding constraints like becoming involuntarily laid off and unemployed (Garboua, Montmarquette, \& Simonnet, 2001). Higgins, Duxbury, \& Irving (1992) claimed that work-family interference undermines quality of occupational life because working conditions (long hours, work overload) behind this conflict also induce dissatisfaction. Frone et al. 1997) argued that by a different logic, inter-role conflict may create job dissatisfaction indirectly by diminishing the quality of private life, that is, heavy job obligations drain time, energy, and attention away from non-work roles, hampering compliance with those roles. According to Kossek \& Ozeki (1998) the difficulties balancing occupational and home demands breed job dissatisfaction. Wadhwa, Verghese, \& Wadhwa, (2011, p. 109) outlined,

When negative stress is high it reduces job satisfaction. When a job does not correspond with employee's personal life, or is the source of anxiety and confusion, it's stressful. Work conditions: Work places must be in normal conditions allowing employee to do their job properly. In work places where there is not sufficient conditions employee motivation level decreases and such a situation affects employee job satisfaction negatively. Supervisors: Managers are one of the main factors which affect job satisfaction. Managers interested in employees' work, assisting them in solution of their work related and personal life problems and also developing informal relations together with the formal ones are increasing employees' job satisfaction.

Do Monte, (2010) tested the effect of age on job dissatisfaction and found that older workers tend to have a lower dissatisfaction. Whereas Isles (2004) tried to identify the role of gender on job dissatisfaction and found that men are much more dissatisfied than the women. Robbins, (2003) said that the extrinsic factors, described as hygiene factors, leading to job 
dissatisfaction include pay, physical working conditions, job security, company policies, quality of supervision and relationship with others. Absence of the extrinsic factors (like salary, fringe benefits, safety, level of support by administration, and job security, or a deficiency in the level of these factors is often associated with job dissatisfaction (Johnson \& Johnson, 1999), and no doubt effect attitudes surrounding the work environment and staff morale and productivity (DeBruyne, 2001). Herzberg's motivatorhygiene also called two-factor theory is built around two sets of factors that can be used to describe or predict employee attitudes about work. Herzberg's hygiene continuum includes things like: company policy, salary, working conditions, and interpersonal relations that are hygiene factors and are often referred to as extrinsic rewards and relate to the job situation or environment. The theory suggests that absence of these factors can result in job dissatisfaction. His motivator continuum points to: achievement, recognition advancement, responsibility, and work itself as motivators that determine job satisfaction. These motivators are considered intrinsic rewards that deal directly with the relationship a person has with his or her job, and are more satisfying (DeBruyne. 2001).

The intrinsic factors appeared very infrequently when respondents described events that were dissatisfying. These factors can prevent or cause dissatisfaction. Herzberg terms these factors 'hygiene factors' or 'dissatisfiers,' in a later publication also 'maintenance factors' (Herzberg, 1966). Based on the Herzberg et al. (1959) model assumes motivators will be referred to more often in the context of job satisfaction and positive events and hygiene factors will be referred to more often in the context of dissatisfaction and negative events. Herzberg started the study job satisfaction in the 1950's in Pittsburg. The basis of Herzberg's work is in the Maslow's Hierarchy of Needs. He started with the idea that what causes the job satisfaction are the opposite of those things that cause job dissatisfaction. Hygiene factors, or dissatisfiers, are those that the employee expects to be in good condition. As motivators are those that in present cause satisfaction, on the other hand hygiene factors don't cause satisfaction but if they are lacking, it causes job dissatisfaction. Salanova, \& Kirmanen, (2001) conducted a survey among the employees of Prisma Mikkeli and he found that the employees were not so satisfied with the money issue. Thus they argued that, in a long run this situation might cause job dissatisfaction and a decline in work motivation (Salanova, \& Kirmanen, 2001) Job dissatisfaction also may increase for temporary jobs \& less time spent for schooling of workers and tends to decrease with age (more), higher wages (Do Monte, 2010). Thus the variable tenure is a good predictor in determining job dissatisfaction and, in general, the more time the worker 
spent on the same job, the lower is the probability to seek for another job (DoMonte, (2010).

Dissatisfaction with one's job may result in higher employee turnover (Chaulagain, \& Khadka, 2012). Mobley's (1977) model suggests that thinking of quitting is the next logical step an employee experiences after dissatisfaction, but there are several other steps an employee might undergo before actually quitting. Those steps include: evaluation of expected utility of search and cost of quitting, intention to search for alternatives, search for alternatives, evaluation of alternatives, comparison of alternatives vs. present job, and intending on leaving (Mobley, 1977). In some study the relationship between job dissatisfaction and employee turnover is described as a process in which job dissatisfaction is the first step, followed by intention to leave, which finally, in some cases, can result in actual turnover (Mobley et al., 1978; Bannister and Griffith, 1986). Griffeth and Hom (1991) proposed that dissatisfaction may stimulate a general predisposition to withdraw, thus mobilizing more specific withdrawal intentions and employees are most apt to engage in the behavioral response of exit when experiencing dissatisfaction. Testing theories about how dissatisfaction progresses into withdrawal have dominated turnover research during the past 25 years (Hom, Caranikis-Walker, Prussia, \& Griffeth, 1992; Hom \& Griffeth, 1995). Such preoccupation with the "intermediate linkages" between job attitudes and resignations has clarified the termination process and identified new constructs mediating the dissatisfaction $\rightarrow$ quit sequence (Mobley, 1977). Moreover, intermediate-linkage models offer practical insights into how firms can short-circuit the dissatisfaction $\rightarrow$ departure route. It is thus imperative to garner more insight into the process by which dissatisfaction activates turnover. Hom \& Griffeth (1991) formulated a model which offered a more complete understanding of how dissatisfaction drives quits. Following figure 1 shows the model: 


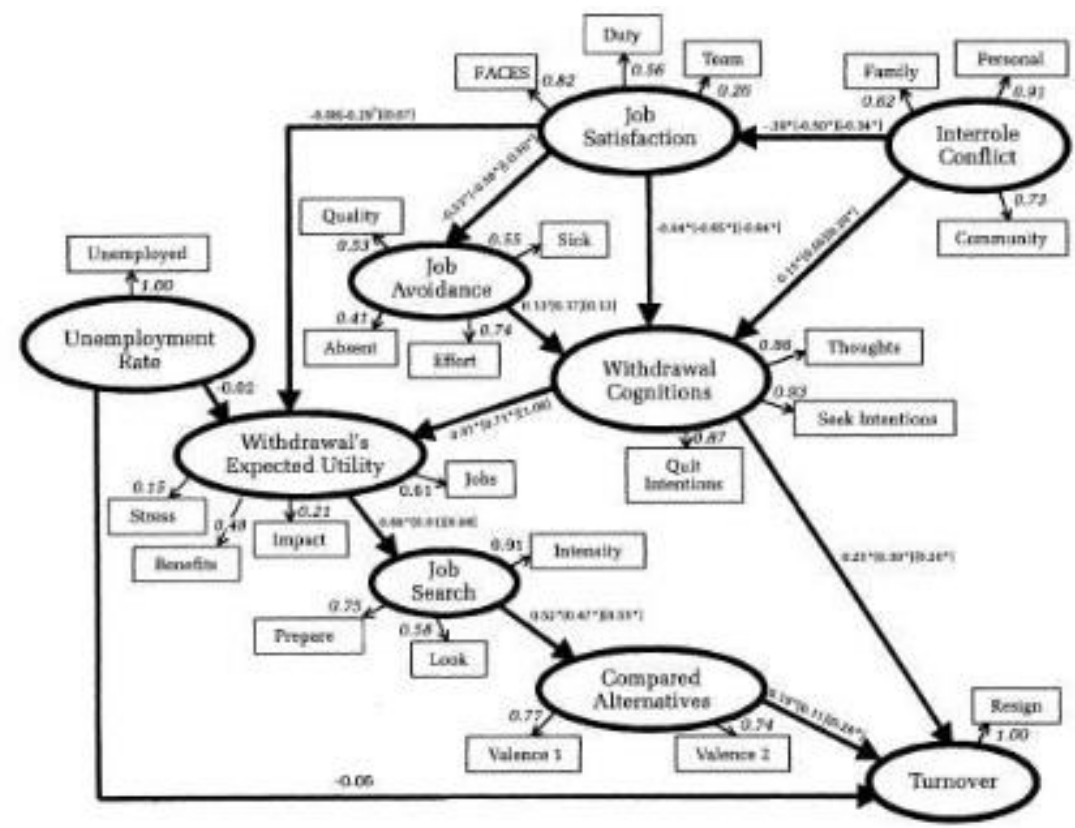

Source: Hom, \& Griffeth, 1991 "A structural equations modeling test of a turnover theory: Cross-sectional and longitudinal analysis". Journal of Applied Psychology, 76:350-366.

Figure 1: How Dissatisfaction Translates into Turnover: Expanded Hom-Griffeth Model

Delfgaauw (2007) argues that its relevance is based on assumption that dissatisfied workers are more likely to search a new job than satisfied workers. he points out three main reasons that workers may leave their current job and search for a new one: (i) discomfort with an organization's specific job domain, like management; (ii) availability of a new job opportunity which yields higher expected utility than the current job; (iii) a feeling that some aspects of their current job can be improved upon. A substantial body of literature reports that job satisfaction is negatively associated with turnover intention. Following this line, Mathieu \& Zajac (1990) and Hom \& Grifeth (1995) argue that organizational commitments are negatively correlated with intention to quit, which, in turn is correlated with job satisfaction. And, Delfgaauw (2007) affirms that for some job domains, the conditions may vary sufficiently across jobs within an organization to make an internal job change a viable option. Therefore, job satisfaction/dissatisfaction in the labor market should be seen as an important variable for understanding the dynamics of employment. The more knowledge we have about job satisfaction, more we understand the issue of turnover. The importance of studying the dynamics of the labor market, especially the job quits, is based on the fact that workers who stay longer on one job position, the employee acquire more experience and skills in performing their tasks, achieving greater productivity. But if this individual 
leaves his employment, the company will have to hire a substitute, paying at least the costs of hiring and training, and possibly seeing declines in productivity. The effects of such dissatisfaction are being felt in higher rates of absence, higher rates of turnover, lower levels of customer satisfaction and ultimately lower levels of productivity (Isles, 2004). March and Simon (1958) argued that voluntary employee departure results from two main factors. The first one is the perception about ease of movement from job to job that has evolved to mean perceived job alternatives. The second one is the desirability of movement that has evolved to mean job satisfaction. It is also supported in the work of Mobley (1977) that argues that staff turnover results from a particular combination of job dissatisfaction and perceived job alternatives. Do Monte, (2010) found in one of his study that the percentage dissatisfied workers who become unemployed is higher compared to those who remained employed or who have become economically inactive. So there is a positive relationship between job dissatisfaction and a future job turnover.

\section{Objectives of the study}

The main objective of the study is to show the rate of turnover in three different situations as: I) being dissatisfied with the previous job; II) availability of job in the market and III) (search for) better alternative job. However, the most concrete directions covered in this study are:

1. To explore the factors responsible for job dissatisfaction.

2. To provide a demographic information about the rate of leaving jobs;

3. To identify the rate of leaving job on the basis of public and private jobs;

\section{Materials and methods}

This research was based on a field work conducted in two largest cities of Bangladesh: Dhaka and Chittagong. For the convenience of our study, we selected 150 employees who have the experience of leaving one or more jobs. We conducted a questionnaire survey from August, 2013 to April, 2014. The questionnaire included three different situations in which turnover occurred in Bangladesh. It also contained a set of variables which frequently cause job dissatisfaction (Appendix 1). Both the primary and secondary data were used in the present study. Secondary data and information were collected from the existing literature in the said field.

The survey covered 150 employees of different organization who leave their previous jobs. Among the questionnaire 146 responses were received. Off them 6 unusable responses were found. Eliminating those 140 respondents was used for this study. Since the total number of people varies 
to leave the job in different situation and in different organizations, we selected this sample size using convenient random sampling method. The areas of sampling were mainly Dhaka and Chittagong: two large cities in Bangladesh. A structured questionnaire with both closed and open ended questions was used for collecting primary data. For the closed ended questions we use five point Likert scale, where $1=$ strongly agree, $2=$ agree, $3=$ neutral (neither agree nor disagree), 4= disagree, and 5= strongly disagree. Finally, Statistical Package for Social Science (SPSS), Microsoft Excel was used to analyze and interpret the data.

\section{Results and discussion}

\section{Demographic figure of turnover}

Analyzing the questionnaire after survey following rate of turnover are found for the male $\&$ female and for private $\&$ public jobs:

Table 1: Demographic figure of turnover:

\begin{tabular}{|ll|}
\hline Particulars & Percentages \\
\hline Quit rate for the male & $87.86 \%$ \\
\hline Quit rate for the females & $12.14 \%$ \\
\hline Quit rate for the govt. job holders & $3.57 \%$ \\
\hline Quit rate for the private job holders & $96.43 \%$ \\
\hline
\end{tabular}

From the above table we find that the rate of job turnover among the male $(87.86 \%)$ is much more than that of for female $(12.14 \%)$ this finding is supported by the findings of Isles N. (2004) and similarly the rate is very much high $(96.43 \%)$ in case of private jobs comparing to the public jobs $(3.57 \%)$.

\section{The rate of turnover in three different situations}

Following rate of job turnover are found in three different situations. Table 2 shows it at a glance:

\begin{tabular}{|ll|}
\hline Situations & Rate of job turnover \\
\hline Dissatisfied with previous job & $33 \%$ \\
\hline Availability of job in the market & $25 \%$ \\
\hline (Search for) better job (relative dissatisfaction $^{1}$ ) & $52.5 \%$ \\
\hline
\end{tabular}

*Percentages will not add to 100 because many of the respondents experience more than one situation

\section{Factors responsible for job dissatisfaction}

To identify the factors which are responsible for job dissatisfaction are explored through the factor analysis method:

The Theory of On-The-Job Search explains the behaviour of employed individuals who search for a better job while others do not. For more details see Lambert (1991) and Allen and Van Der Velden (2001). 


\section{Communalities}

Communalities show how much of the variance in the variables has been accounted for by the extracted factors. For instance in the following table (table 1), over $83 \%$ of the variance in very much challenging job, over $82 \%$ of the variance in traditional job, over $75 \%$ of the variance in poor management is accounted for is accounted for while $40.7 \%$ of the variance in less job security is accounted for.

Table 1: Communalities

\begin{tabular}{|l|l|l|}
\hline variables & Initial & Extraction \\
\hline Low salary & 1.000 & .458 \\
\hline Low increment & 1.000 & .486 \\
\hline Less job security & 1.000 & .407 \\
\hline Excessive work pressure & 1.000 & .666 \\
\hline Excessive supervision & 1.000 & .679 \\
\hline Poor working environment & 1.000 & .574 \\
\hline Unhelpful colleagues & 1.000 & .432 \\
\hline Poor administration & 1.000 & .740 \\
\hline Poor management & 1.000 & .755 \\
\hline More working hours & 1.000 & .594 \\
\hline Rough and tough supervisors \& bosses & 1.000 & .633 \\
\hline Absent of pension facility & 1.000 & .632 \\
\hline Absent of gratuity & 1.000 & .754 \\
\hline Absent of provident facilities & 1.000 & .746 \\
\hline Traditional job & 1.000 & .827 \\
\hline Very much challenging job & 1.000 & .838 \\
\hline Less scope of growth \& development & 1.000 & .563 \\
\hline $\begin{array}{l}\text { Inappropriate performance appraisal and } \\
\text { recognition }\end{array}$ & 1.000 & .570 \\
\hline
\end{tabular}

Extraction Method: Principal Component Analysis.

\section{Total Variance Explained}

The next item shows all the factors extractable from the analysis along with their eigenvalues, the percent of variance attributable to each factor, and the cumulative variance of the factor and the previous factors. Notice that (table 2, which has given in the appendix 1) the first factor accounts for $25.760 \%$ of the variance, the second $13.728 \%$, the third $9.455 \%$, the fourth $7.977 \%$ and the fifth $6.154 \%$. All the remaining factors are not significant

\section{Scree Plot}

The scree plot is a graph of the eigenvalues against all the factors whereas the eigenvalue refers to the standardized variance associate with a particular factor. The graph is useful for determining how many factors to retain. The point of interest is where the curve starts to flatten. It can be seen that the curve begins to flatten between factors 3 and 4 . On the following 
graph (graph 1) we can see that factors 1 to 5 possess the eigenvalues more than 1 and the remaining factors (factor 6 to 18) have the eigenvalues of less than 1 , so only five factors have been retained.

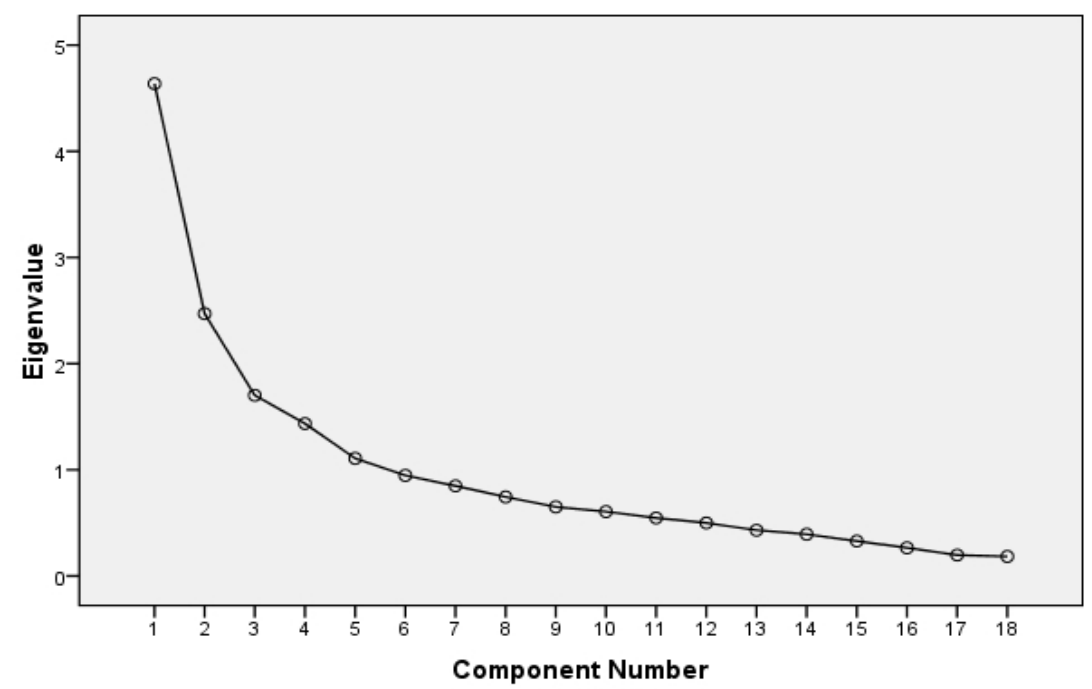

Graph 1: the scree plot

\section{Rotated Component (Factor) Matrix}

The idea of rotation is to reduce the number factors on which the variables under investigation have high loadings. Rotation does not actually change anything but makes the interpretation of the analysis easier. Looking at the table (table 3) below, we can see that poor working environment, poor administration and poor management are substantially loaded on Factor (Component) 1; excessive work pressure, excessive supervision, more working hours and rough and tough supervisors and bosses are substantially loaded on Factor 2; Absent of pension facility, Absent of gratuity and Absent of provident facilities are substantially loaded on Factor 3; traditional job and very much challenging job are substantially loaded on the factor 4; Low increment, Less scope of growth \& development and Inappropriate performance appraisal and recognition are substantially loaded on Factor 5.

Table 3: Rotated Component Matrix ${ }^{\mathrm{a}}$

\begin{tabular}{|l|l|l|l|l|l|}
\hline \multirow{2}{*}{ variables } & \multicolumn{4}{l|}{ Component (Factor) } & \multicolumn{4}{l|}{} \\
\cline { 2 - 6 } & 1 & 2 & 3 & 4 & 5 \\
\hline Low salary & & & & & \\
\hline Low increment & & & & & .551 \\
\hline Less job security & & & & & \\
\hline Excessive work pressure & & .779 & & & \\
\hline Excessive supervision & & .806 & & & \\
\hline Poor working environment & .686 & & & & \\
\hline
\end{tabular}




\begin{tabular}{|l|l|l|l|l|l|}
\hline Unhelpful colleagues & & & & & \\
\hline Poor administration & .830 & & & & \\
\hline Poor management & .843 & & & & \\
\hline More working hours & & .750 & & & \\
\hline $\begin{array}{l}\text { Rough and tough } \\
\text { supervisors \& bosses }\end{array}$ & & .625 & & & \\
\hline Absent of pension facility & & & .762 & & \\
\hline Absent of gratuity & & & .837 & & \\
\hline $\begin{array}{l}\text { Absent of provident } \\
\text { facilities }\end{array}$ & & & .830 & & \\
\hline Traditional job & & & & .889 & \\
\hline Very much challenging job & & & & -.895 & \\
\hline $\begin{array}{l}\text { Less scope of growth \& } \\
\text { development }\end{array}$ & & & & & .627 \\
\hline $\begin{array}{l}\text { Inappropriate performance } \\
\text { appraisal and recognition }\end{array}$ & & & & & .732 \\
\hline
\end{tabular}

Extraction Method: Principal Component Analysis.

Rotation Method: Varimax with Kaiser Normalization.

a. Rotation converged in 7 iterations.

\section{Composition of factors}

From the above table we find the specific variables leaded to specific factor(s). With those we can construct the following table (table 4) which shows the factors composed with the variables used in this study as the causes of job dissatisfaction. Factor 1 is named as working environment \& administration which is composed with poor working environment, poor administration, poor management; similarly factor 2, named as supervisors \& working hours composed with Excessive work pressure, Excessive supervision, More working hours and Rough \& tough supervisors and bosses and other remaining factors are shown in the following table.

Table 4: Composition of factors

\begin{tabular}{|l|l|l|}
\hline Factors & Factor name & Loaded variables \\
\hline $\begin{array}{l}\text { Factor } \\
\mathbf{1}\end{array}$ & $\begin{array}{l}\text { Working environment \& } \\
\text { Administration }\end{array}$ & $\begin{array}{l}\text { Poor working environment } \\
\text { Poor administration } \\
\text { Poor management }\end{array}$ \\
\hline $\begin{array}{l}\text { Factor } \\
\mathbf{2}\end{array}$ & $\begin{array}{l}\text { Supervisors \& Working } \\
\text { hours }\end{array}$ & $\begin{array}{l}\text { Excessive work pressure } \\
\text { Excessive supervision } \\
\text { More working hours } \\
\text { Rough and tough supervisors and bosses }\end{array}$ \\
\hline $\begin{array}{l}\text { Factor } \\
\mathbf{3}\end{array}$ & $\begin{array}{l}\text { Security of } \\
\text { Income(future) }\end{array}$ & $\begin{array}{l}\text { Absent of pension facility } \\
\text { Absent of gratuity } \\
\text { Absent of provident fund facilities }\end{array}$ \\
\hline $\begin{array}{l}\text { Factor } \\
\mathbf{4}\end{array}$ & Job Challenges & $\begin{array}{l}\text { Traditional job } \\
\text { Very much challenging job }\end{array}$ \\
\hline $\begin{array}{l}\text { Factor } \\
\mathbf{5}\end{array}$ & $\begin{array}{l}\text { Scope of Growth and } \\
\text { Development }\end{array}$ & $\begin{array}{l}\text { Low increment } \\
\text { Less scope of growth and development Inappropriate } \\
\text { performance appraisal and recognition }\end{array}$ \\
\hline
\end{tabular}




\section{Conclusion}

The empirical evidences show that, most of the organizations are very much reluctant to offer the basic facilities to their employees and thus it results dissatisfaction or alternative dissatisfaction (the situation whereby the employees are not fully dissatisfied with their current jobs but leave those for the search of better alternative jobs) and which gradually leads to job turnover. The variables which cause job dissatisfaction are showed in the findings of the study. Knowledge that, working environment \& administration, supervisors \& working hours and security of income (future) etc. seem to be the greatest importance for the employers an opportunity to counteract job dissatisfaction and consequently staff turnover (Tham 2006). By adopting sound staff policies under which people feel rewarded, valued and well taken care of, it should, after all, be easier to prevent staff from leaving for reasons of poor management than for reasons of demanding, difficult and complicated tasks. So the organizations experience excessive rate of job turnover should be concentrated to consider those factors to retain their employees.

\section{References:}

Allen, J., Van Der Velden, R. (2001). Educational mismatches versus skill mismatches: effects on wages, job satisfaction, and on-the-job search. Oxford Economic Papers, 53, 434-452.

Bannister, B. D., \& Griffith, R. W. (1986). Applying A Causal Analytic Framework to the Mobley, Horner and Hollingsworth Turnover Model: A Useful Reexamination. Journal of Management, 12(3), 433-443.

Chaulagain, N., \& Khadka, D. K. (2012). Factors Influencing Job Satisfaction among Healthcare Professionals at Tilganga Eye Centre, Kathmandu, Nepal. International Journal of Scientific \& Technology Research, 1(11), 32-36.

DeBruyne, J. W. (2001). A Study To Identify the Factors Responsible for Job Dissatisfaction and Low Teacher Morale. MS thesis, The Graduate School, University of Wisconsin-Stout.

Delfgaauw, J. (2007). The Effect of Job Satisfaction on Job Search: not just Whether, but also Where. Labour Economics, 14(3), 299-317.

DoMonte, P. A. (2010). Job Dissatisfaction and Labour Turnover: Evidence. $\mathrm{Ph}$. D theses, Federal University of Paraiba (UFPB) - Brazil.

Frone, M., Yardley, J., \& Markel, K. (1997). Developing and Testing an Integrative Model of the Work-Family Interface. Journal of Vocational Behavior, 50, 145-167. 
Garboua, L. L., Montmarquette, C., \& Simonnet, V. (2001). Job Satisfaction and Quits: Theory and Evidence from the German Socioeconomic Panel. Scientific Series, June 31, p. 4.

Herzberg, F. (1966). Work and the Nature of Man. World Publishing Company, Cleveland and New York.

Herzberg, F., Mausner, B., \& Synderman B. B. (1959). The motivation to work. John Wiley \& Sons: New York.

Higgins, C., Duxbury, L., \& Irving, R. (1992) Work-Family Conflict in the Dual-Career Family. Organizational Behavior and Human Decision Processes, 51, 51-75.

Hom, P., \& Griffeth, R. (1996). Structural Equations Modeling Test of a Turnover Theory: Cross-Sectional and Longitudinal Analysis. Journal of Applied Psychology, 76, 350-366.

Hom, P., \& Griffeth, R. (1995). Employee turnover. Cincinnati, OH, Southwestern.

Hom, P., Caranikis, W. F., Prussia, G., \& Griffeth, R. (1992). A MetaAnalytical Structural Equations Analysis of A Model of Employee Turnover. Journal of Applied Psychology, 77, 890-909.

Isles, N. R. (2004). The Joy of Work. The Work Foundation, June 25, p. 13

Johnson, W. L., \& Johnson, A. M. (1999). World Class Schools in The $21^{\text {st }}$

Century. NASSP Bulletin, 83(606), 26-32. [Online] Available at: http://www.libproxy.uwstout.edu:cgi/bin/webcl.../ (May 10, 2014).

Jose, D. (2013). What Are The Main Causes of Employee Turnover.

Synergita blog.[Online] Available at:

http://blog.synergita.com/2013/08/main-causes-of-employee-turnover (January 3, 2014).

Kossek, E., \& Ozeki. C. (1998). Work-Family Conflict, Policies, and the Job-Life Satisfaction Relationship: A Review and Directions for Organizational Behavior-Human Resources Research. Journal of Applied Psychology, 83, 139-149.

Lambert, S. J. (1991). The combined effects of job and family characteristics on the job satisfaction, job involvement, and intrinsic motivations of men and women workers.Journal of Organizational Behavior, 12, 341-363.

March, J., \& Simon, H. (1958). Organizations, John Wiley, New York. Mathieu, J. E., \& Zajac, D. M., (1990). A Review and Meta-Analysis of the Antecedents, Correlates, and Consequences of Organizational Commitment. Psychological Bulletin, 108, 171-194.

Mobley, W., Horner, S., \& Hollingsworth, A. (1978). An Evaluation of Precursors of Hospital Employee Turnover. Journal of Applied Psychology, 63, 408-414. 
Mobley, W. (1977). Intermediate Linkages in the Relationship Between Job Satisfaction And Employee Turnover. Journal of Applied Psychology, 62, 237-240.

Robbins, S. (2003). Organizational Behavior. Prentice-Hall Publishing, New York.

Salanova, A., \& Kirmanen, S. (2010). Employee Satisfaction and Work Motivation. Bachelor's Thesis of Business Management. Mikkeli University of Applied Sciences.

Tham, P. (2006). Why Are They Leaving? Factors Affecting Intention to Leave among Social Workers in Child Welfare. British Journal of Social Work, 37, 1225-1246.

Wadhwa, Daljeet, S., Verghese, M., \& Wadhwa, Dalvinder, S. (2011). A Study on Factors Influencing Employee Job Satisfaction-A Study in Cement Industry of Chhattisgarh. International Journal of Management \& Business Studies, 1(3), 109-111.

\section{Appendix 1}

Table 2: Total Variance Explained

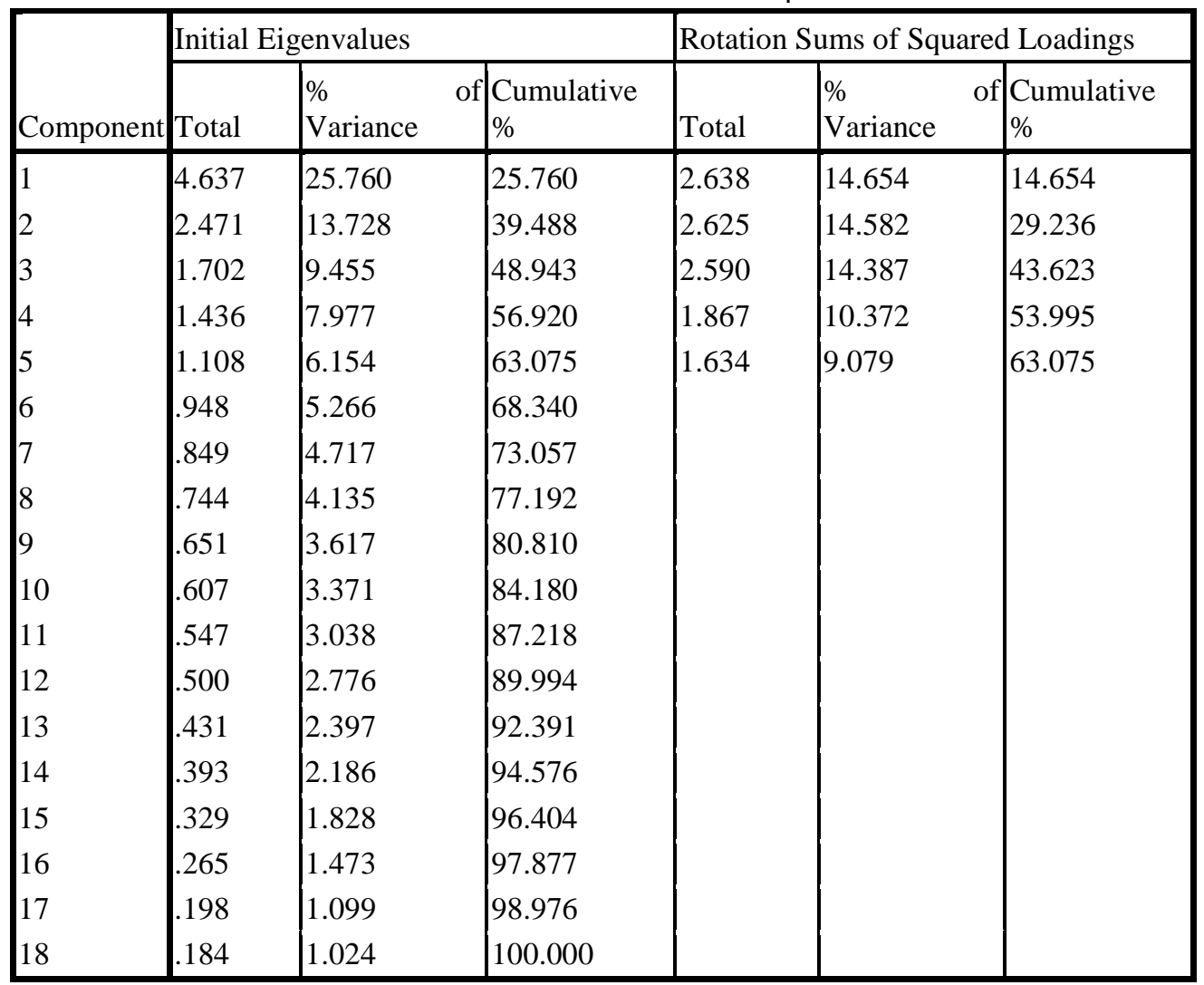

Extraction Method: Principal Component Analysis. 